\title{
Metastatic melanoma
}

\author{
Christina Maria Steger, ${ }^{1,2}$ Arjeta Mehmeti, ${ }^{3}$ Nikolaus Fischler ${ }^{4}$
}

${ }^{1}$ Department of Pathology, Innsbruck Medical University, Innsbruck, Austria

2Department of Pathology, Ludwig-Maximilians-University Munich, Munich, Germany

${ }^{3}$ Department of Neurosurgery, Innsbruck Medical University, Innsbruck, Austria

${ }^{4}$ Department of Cardiac Surgery, Innsbruck Medical University, Innsbruck, Austria

Correspondence to Dr Christina Maria Steger, Christinamariasteger@gmail.com

\section{DESCRIPTION}

First described by Lucke in 1869 , melanoma of the nasal cavity and paranasal sinuses is estimated to account for less than $1 \%$ of all malignant melanomas and $2-8 \%$ of malignant neoplasms of the sinonasal tract. ${ }^{1}$

Malignant melanoma of the nose and paranasal sinuses can be a devastating disease, typically presenting at an advanced stage, with a 5-year survival rate ranging between $20 \%$ and $35 \%{ }^{2}$ It is an uncommon process, often misdiagnosed both clinically and pathologically.

The peak age incidence is between the fifth and eighth decade, ${ }^{3}$ seen slightly more commonly in men than women.

A 53-year-old male patient had a 2-month history of progressively worsening left-sided epistaxis and nasal obstruction and therefore consulted his physician.

A CT scan showed a widespread but continuous tumour mass in the left nasal cavity and the left maxillary sinus (figure $1 \mathrm{~A}$ ). The diagnosis of malignant melanoma was made by intranasal biopsy.

A further total body CT scan, immediately performed after the first CT scan, revealed extended metastases of the thyroid gland, lungs, epicardium and pericardium of the heart, liver, stomach, pancreas, colon, peritoneal cavity, urinary bladder, bones and jugular, omental and mesenterial lymph nodes.

The skin metastases were located on the chest wall, the right angulus mandibulae and the left axilla. The patient underwent debulking of the tumour mass in the left paranasal sinus and received two chemotherapeutical cycles of dacarbazine.

Two months after initial diagnosis he was admitted to hospital for the third round of chemotherapy. But in the night he complained about worsening abdominal pain and died a few hours later.
Autopsy revealed tumour haemorrhage as cause of death with 3 litres of blood and blood clots in the abdominal cavity (postmortem photographs: heart metastases figure $1 \mathrm{~B}$; liver and gastric metastases figure 1C).

\section{Learning points}

- Malignant melanoma is a rare disorder of the nasal cavity and paranasal sinus mucosa.

- Sinonasal malignancies produce few, if any, signs while the tumour is in its early stages (eg, unilateral epistaxis and nasal obstruction).

- The patient and clinician often ignore or minimise the initial presentation of these tumours and treat early-stage malignancy as a benign sinonasal disorder. Treatment includes surgery, chemotherapy or radiation therapy.

- Melanoma with distant metastases is generally considered incurable.

Competing interests None.

Patient consent Obtained.

\section{REFERENCES}

1. Rinaldo A, Shaha AH, Patel SG, et al. Primary mucosal melanoma of the nasal cavity and paranasal sinuses. Acta Otolaryngol 2001;121:979-82.

2. Manolidis S, Donald PJ. Malignant mucosal melanoma of the head and neck: review of the literature and report of 14 patients. Cancer 1997:80:1373-86.

3. Batsakis JG, Suarez P, El-Naggar AK. Mucosal melanomas of the head and neck. Ann Otol Rhinol Laryngol 1998;107:626-30
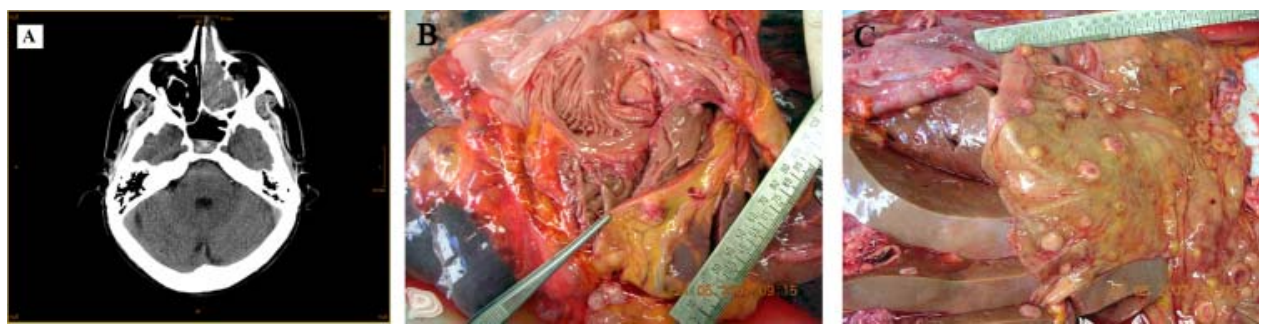

Figure 1 (A) CT scan showing the tumour mass in the left nasal cavity and the left maxillary sinus, destroying the medial orbital wall. (B) Cardiac pericardial, epicardial and myocardial melanoma metastases. (C) Liver and gastric metastases. 


\section{BMJ Case Reports}

This pdf has been created automatically from the final edited text and images.

Copyright 2012 BMJ Publishing Group. All rights reserved. For permission to reuse any of this content visit http://group.bmj.com/group/rights-licensing/permissions.

BMJ Case Report Fellows may re-use this article for personal use and teaching without any further permission.

Please cite this article as follows (you will need to access the article online to obtain the date of publication).

Steger CM, Mehmeti A, Fischler N. Metastatic melanoma. BMJ Case Reports 2012;10.1136/bcr-02-2012-5754, Published XXX

Become a Fellow of BMJ Case Reports today and you can:

- Submit as many cases as you like

- Enjoy fast sympathetic peer review and rapid publication of accepted articles

- Access all the published articles

- Re-use any of the published material for personal use and teaching without further permission

For information on Institutional Fellowships contact consortiasales@bmjgroup.com

Visit casereports.bmj.com for more articles like this and to become a Fellow 